\title{
Study of the Relationship between Corporate Governance and Financial Performance of the Companies Listed in Tehran Stock Exchange Market
}

\author{
Roghayeh Manafi
}

Department of Financial Management, Sari Branch, Islamic Azad University, Sari, Iran R.phd92@yahoo.com

\section{Dr. Amir Mahmoudian*}

Department of Accounting, Savadkooh Branch, Islamic Azad University, Savadkooh, Iran Amirmahmoudian@yahoo.com

\section{Dr. Ali Zabihi}

Department of Accounting, Aliabad Katoul Branch, Islamic Azad University, Aliabad Katoul, Iran Zabihi52@yahoo.com

Doi:10.5901/mjss.2015.v6n5p56

\section{Abstract}

In this research, relationship between corporate governance and financial performance is investigated. Data from 110 companies listed in Tehran stock exchange market from 2007 to 2013 has been used in analysis. Testing the hypotheses was carried out through linear regression. Results revealed that managerial ownership has a negative and significant relationship with financial performance while institutional ownership has a positive relationship with financial performance. Major shareholders have negative relationship with financial performance. Moreover, there is a negative and significant correlation between duality of CEO's tasks and firms' financial performance.

Keywords: corporate governance-financial performance- Assets efficiency rate

\section{Introduction}

One of the principal factors of improvement of economical efficiency is business steering system (corporate governance) that involves a collection of relationships between CEO, board of directors, shareholders and other stakeholders. Business steering system provides a system through which objectives of business are set and tools for reaching goals and monitoring performance are determined. (Mokarrami,2006). Today one of the most important financial issues of firms lies in measuring their performance. Measuring financial performance of companies, since many decisions are made inside and outside the company, is of importance. Decision making related to investments, companies' capital increase, Agency relationship and many other decisions, are all based on measuring performance. The concept of corporate governance stands for the governing method in a public company and based on that, the way company responses the shareholders and also other organizational stakeholders are formed.

Therefore, it is considered significant in regard to companies' performance and also all the society and in recent years has appealed to many (Osman Imam and Malik, 2007;90). In Shleifer and Vishny's idea (1997), corporate governance mechanisms are strategies for assuring that despite the representative relationship between owner and manager and conflict of their interests, management searches for maximizing stockholders wealth by enhancing and improving financial performance of the company.

Although characteristics of corporate governance, have different roles in ensuring the companies' success, eventually it is only the responsiveness role that impacts the commercial economics. According to the investigations, if companies try for improvement and development of corporate governance, it will have a positive influence on the performance and value of the company (Lindelof, 2005)

This experimental research examines the impact of corporate governance on the financial performance of the companies listed in Tehran Exchange Market. The significance of the research, in an experimental way, reveals the relationship between corporate governance and financial performance of the companies and other influential factors to 
the managers, investors and other decision-makers.

\section{Literature Review}

Qaemi and Shahryari(2009), in their project called "Corporate Governance and Financial Performance of Companies", studied 77 companies that were accepted in stock market from 2003-2005 and concluded that there is no significant correlation between arrangement of board of directors and financial performance of firms.

Nikbakht et al. (2010) investigated the relationship between the attributes of boards of directors and company's performance. In order to measure company's performance grade, they used 5 criteria of revenue growth, operational profit growth, net profit growth, assets efficiency and return on equity. Their findings reveal that board of directors has no significant influence on company performance in Iran's stock market.

Marck, Shleifer, and Vishny (1988) and Hermalin and Weisbach (1991) investigated the effect of ownership structure on company performance. Results of their research demonstrate an important and positive correlation between ownership structure and company performance.

Corporate governance, as a system connecting several scientific branches such as accounting, financial management, economy and law and maintaining balance between social and economical objectives and group and individual goals, encourages and enhances efficient and optimal use of resources and accountability of companies in regard to other stakeholders in the company. On the other hand, implementation of corporate governance system can lead to optimal appropriation of resources and improvement of transparency of financial information spread in the market and eventually economical development (John and Senbet, 1988, quoted by Ghaemi and Shahriari, 2009; 114).

Coleman and Bikpi studied the relationship between the arrangement of board of directors and duality of board of directors and company performance in Ghana stock exchange market in years from 1990 to 2001. Results of the analysis of this model confirmed a negative correlation between board of directors' arrangement with company performance and a positive correlation between roles of head of board of directors and CEO with company performance in Ghana.

Gedajlovic and Shapiro (2002) explored the relationship between ownership localization and financial performance in Japanese companies. Results of their research showed a significant and positive relationship between these two variables.

Cui and Mac (2002) tested the correlation between management ownership and performance of research and development companies. Furthermore, observation expenses of bond owners increases with the fall of management ownership level.

Himmelberg, Hubbard and Palia (1999) found no relationship between outside members and relational performance, while Brown and Caylor (2004) and De Miguel, A., J. Pindado and C. de la Torre concluded that there is a positive relationship between outside managers and performance.

\section{Research Hypotheses}

First hypothesis: there is a significant relationship between management ownership and financial performance of companies.

Second hypothesis: there is a significant relationship between institutional shareholders percentage and financial performance of companies.

Third hypothesis: there is a significant relationship between block shareholders percentage and financial performance of companies.

Fourth hypothesis: there is a significant relationship between CEO's task duality and financial performance of companies.

\section{Research Methodology}

Since the current research focuses on the relationship between variables, it is descriptive and of correlational and ex-post facto kind of research. In this category of studies, the goal is to examine the relationship between variables and data are gathered and analyzed from their natural setting or from past events which have occurred without intervention of the researcher. 


\section{Statistical Population}

Statistical population of the current research is all the companies accepted in Tehran stock exchange market in a 7-year period, from 2007 to 2013. In this research, the companies lacking the following requirements were eliminated and finally all the remaining companies were selected for analysis.

- Companies should own full information for all financial statements such as balance sheet, cash flow statements, income statement

- Their financial year should end in Esfand $29^{\text {th }}$.

- Companies should be active in stock exchange market during research period.

- They shouldn't change their financial year during research.

- Company should not be of investment or financial intermediary type.

\section{Method of Data Collection and Analysis}

Data collection was done in 2 stages in this research. In the first stage, for formulation of theoretical foundation of research, library method and for the second stage, for data collection, sample companies' documents and papers, such as financial statements in CDs presented by Tehran Stock Exchange and Research, Development and Islamic Studies Management of Stock Exchange (http://rdis.ir) have been used. Analysis of data and test of hypotheses were done through linear regression and Eviews software.

Variables and Research Model

Independent Variable

Corporate governance that is measured by the following criteria:

- The percentage of company shares that are held by board of directors.

- The percentage of company shares that are held by institutional shareholders. (institutional shareholders involve all legal shareholders)

- The number of block shareholders whose ownership percentage is more than 5 percent of company shares.

- Duality of CEO tasks; that is when CEO is the same as head of board of directors.

Dependant Variable

1. Financial Performance:

2. It $s$ obtained by return on assets that is one of financial scales calculated through dividing net profit plus interest cost by total assets (Jahankhany and Sajadi, 1995). And Tobin's Q ratio that is another tool for measuring financial performance that is calculated by dividing market cap to book value or replacement of assets value (James Tobin, 1978).

Tobin's Q= book value of all assets+ stock market total value

Book value of total assets

\section{Control Variable}

Firm size: this criterion is obtained through natural logarithm of total assets.

Financial Leverage: this criterion is obtained by dividing total debts of the firms by its total assets.

Return on Assets: This criterion is obtained by dividing firm's net profit to total assets.

In the current study, the relationship between corporate governance, financial management decisions and financial performance of the companies in Tehran Stock Exchange Market is tested. Regression models of the research are as follows:

Pattern 1

$\bar{Q} \_$TOBIN $_{t}=\alpha_{1}+\alpha_{2}$ DUAL $_{i t}+\alpha_{3}$ COOW $_{i t}+\alpha_{4} I N S_{i t}+\alpha_{5} M G T_{i t}+\alpha_{6} L E V_{i t}+R O A_{i t}+S I Z E_{i t}+\varepsilon_{t}$

This model is used for testing hypotheses one to four. 


\section{Findings}

\subsection{Descriptive Statistics}

Results of Table.1 demonstrate that average value for financial leverage and return on assets are 0.6523 and 0/5300 respectively and for the firm it is 33.2361 . This way, according to financial leverage, assets of the firm are as much as the firm has the potential to reimburse debts and on the other hand, the average of firm assets conveys that for every Rial invested in assets, 0.53 Rial has been returned. Also firm age shows high activity of the firms under study. In other words, these firms are not in the early years of their activity and have passed the beginning fluctuations of work. Average and median of other variables have been presented in the table below.

Table 1: Descriptive Statistics of Variables

\begin{tabular}{|l|c|c|c|c|c|c|}
\hline Variables & Number & Average & Median & Standard Deviation & Maximum & Minimum \\
\hline Q-Tobin & 741 & 1.4221 & 1.2362 & 0.5919 & 4.6015 & 0.3227 \\
\hline Ownership Concentration & 741 & 0.7587 & 0.8080 & 0.1799 & 0.9998 & 0.0395 \\
\hline CEO Duality & 741 & 0.9109 & 1.0000 & 0.2850 & 1.0000 & 0.0000 \\
\hline Institutional Ownership & 741 & 0.7195 & 0.8173 & 0.2687 & 0.9900 & 0.0100 \\
\hline Management Ownership & 741 & 0.6734 & 0.6980 & 0.1962 & 0.9900 & 0.0100 \\
\hline Financial Leverage & 741 & 0.6523 & 0.6576 & 0.1673 & 0.9714 & 0.0964 \\
\hline Return on Assets & 741 & 0.5300 & 0.3945 & 0.5514 & 2.9258 & -1.3856 \\
\hline Firm Size & 741 & 5.7298 & 5.6808 & 0.5918 & 7.9568 & 4.2464 \\
\hline Book Value to Market Value & 741 & 0.7946 & 0.8089 & 0.2506 & 3.0979 & 0.2173 \\
\hline Accruals & 741 & 0.1391 & 0.0532 & 0.6396 & 4.4294 & -7.1403 \\
\hline Firms Size & 741 & 33.2361 & 36.0000 & 0.5886 & 57.0000 & 6.0000 \\
\hline Investment Expenses & 741 & 0.5616 & 0.4618 & 12.0738 & 3.7974 & 0.0005 \\
\hline Cash & 741 & 0.1810 & 0.0556 & 0.2556 & 0.9778 & 0.0556 \\
\hline
\end{tabular}

\section{Results of Testing Hypotheses}

Table.2 demonstrates the results of assessment of parameters in research model 1. For this statistical model, DurbinWatson Statistic equals 2.3112 and the error term is rejected at 5 error level. The possibility value related to $\mathrm{F}$ statistic is less than 5 percent for specification. This way, null hypothesis based on model specification error is rejected. As a result, significance of the model is accepted with 95percent certainty. Adjusted R-square equals 0.2185 . This test reflects that about 22 percent of dependent variable changes can be described by independent variables. Since model test was not rejected, research hypotheses are investigated.

Table 2. Results of testing research model 1

\begin{tabular}{|l|c|c|c|}
\hline Variable & index & T test & Error level \\
\hline y-intercept & 1.2377 & 8.6859 & 0.0000 \\
\hline Ownership Concentration & -0.0862 & -0.8125 & 0.4168 \\
\hline CEO Duality & 0.0790 & 2.8613 & 0.0044 \\
\hline Institutional Ownership & -0.0274 & -0.2776 & 0.7814 \\
\hline Management Ownership & -0.0476 & -0.6443 & 0.5195 \\
\hline Financial Leverage & 0.5646 & 6.3248 & 0.0000 \\
\hline Assets Efficiency & 0.1982 & 9.6452 & 0.0000 \\
\hline Firm Size & -0.0424 & -3.9116 & 0.0001 \\
\hline R-square & & & 0.3383 \\
\hline Adjusted R-square & & & 0.2185 \\
\hline Durbin-Watson Test & & & 2.3112 \\
\hline F Statistics & & & 2.8252 \\
\hline Possibility F Statistics & & & 0.0000 \\
\hline
\end{tabular}

Hypothesis No. 1 
The purpose of this hypothesis is investigating the existence of a significant relationship between block shareholders percentage (ownership concentration) and financial performance of firms. Therefore, null and alternative statistical hypotheses are as follows:

Null hypothesis:

Hypothesis: there is a significant relationship between block shareholders' percentage (ownership concentration) and financial performance of firms.

According to the results presented in table 2, possibility error level related to null hypothesis is based on the lack of significant impact of ownership concentration on financial performance is 0.4168 that is bigger than 0.05 . Hence, null hypothesis is not rejected. Consequently, ownership concentration has no significant relationship with financial performance.

Hypothesis No. 2

The goal of this hypothesis is to explore if there is a significant relationship between CEO task duality and firms' financial performance. Therefore, statistical null and alternative hypotheses are as follows:

Null hypothesis: There is no significant relationship between CEO task duality and financial performance of firms.

Alternative hypothesis: there is a significant relationship between CEO task duality and financial performance of firms.

According to the findings presented in table 2, possible error rate of null hypothesis based in the lack of significant impact of CEO duality on financial performance equals 0.0044 that is less than 0.05 . Hence, null hypothesis is rejected. As a result, CEO duality has a significant impact on financial performance.

Hypothesis No. 3

The goal of this hypothesis is to explore if there is a significant relationship between institutional ownership and firms' financial performance. Therefore, statistical null and alternative hypotheses are as follows:

Null hypothesis: There is no significant relationship between institutional ownership and financial performance of firms.

Alternative hypothesis: there is a significant relationship between institutional ownership and financial performance of firms.

According to the findings presented in table 2, possible error rate of null hypothesis based on the lack of significant impact of institutional ownership on financial performance equals 0.7814 that is bigger than 0.05 . Hence, null hypothesis is not rejected. As a result, institutional ownership has no significant impact on financial performance.

Hypothesis No. 4

The goal of this hypothesis is to explore if there is a significant relationship between management ownership and firms' financial performance. Therefore, statistical null and alternative hypotheses are as follows:

Null hypothesis: There is no significant relationship between management ownership and financial performance of firms.

Alternative hypothesis: there is a significant relationship between management ownership and financial performance of firms.

According to the findings presented in table 2, possible error rate of null hypothesis based on the lack of significant impact of institutional ownership on financial performance equals 0.5159 that is bigger than 0.05 . Hence, null hypothesis is not rejected. As a result, institutional ownership has no significant impact on financial performance

\section{Conclusion}

In this research, the relationship between corporate governance including ownership concentration, institutional ownership and board of directors' duality of members in regard to firms' financial performance was studied. It was found out that there is a negative and significant correlation between management ownership and CEO duality with firms' financial performance. And institutional shareholders have a positive and significant relationship with financial performance of firms. Furthermore, block shareholders have a negative and significant relationship with firms' financial performance.

\section{References}

Andreou, P.C., Louca, C., Panayides, P.M., 2012. Valuation effects of mergers and acquisitions in freight transportation. Transp. Res. Part E 48, 1221-1234.

Ashbaugh-Skaife, H., Collins, D.W., LaFond, R., 2006. The effects of corporate governance on firms' credit ratings. J. Account. Econ. 4, 
203-243.

Bebchuk, L., Cohen, A., 2004. The Costs of Entrenched Boards. Working Paper. Harvard Law School.

Bebchuk, L., Cohen, A., Ferrell, A., 2004. What Matters in Corporate Governance? Working Paper. Harvard Law School.

Bebchuk, L.A., Stole, L., 1993. Do short-term managerial objectives lead to under- or over-investment in long-term projects? J. Finance. 48, 719-729.

Bebchuk, L.A., Weisbach, M.S., 2010. The state of corporate governance research. Rev. Financ. Stud. 23, 939-961.

Beneish, M., Vargus, M., 2002. Insider trading, earnings quality and accrual mispricing. Account. Rev. 4, 755-791.

Bertrand, M., Mullainathan, S., 2003. Enjoying the quite life? Corporate governance and managerial preferences. J. Polit. Econ. 111 (5), 1043-1075.

Bhagat, S., Black, B., 2002. The non-correlation between board independence and long-term firm performance. J. Corp. L. 27, 231-274.

Bhagat, S., Bolton, B., 2008. Corporate governance and firm performance. J. Corp. Gov. 14, 257-273.

Billett, M., Garfinkel, J., Jiang, Y., 2011. The influence of governance on investment: evidence from a hazard model. J. Financ. Econ. $102(3), 643-670$.

Bohren, O., Cooper, I., Priestley, R., 2009. Real Investment, Economic Efficiency, and Managerial Entrenchment. Working Paper, Tel Aviv University.

Brian J. Bushee, Mary Ellen Carter, Joseph Gerakos.2010. Institutional Investor Preferences for Corporate Governance Mechanisms. Managing corporate performance.

Brown, P., Beekes, W., Verhoeven, P., 2011. Corporate governance, accounting and finance: a review. Account. Financ. 51, 96-172.

Burns, N., Kedia, S., 2006. The impact of performance-based compensation on misreporting. J. Financ. Econ. 79, 35-67.

Bushee, B.J., 1998. Investors on myopic R\&D investment behavior. Account. Rev. 73 (3), 305-333.

Bushee, B.J., 2001. Do institutional investors prefer near-term earnings over long-run value? Contemp. Account. Res. 18 (2), 207-246.

Canil, J., Rosser, B., 2012. Australian evidence on CEO option grants. Multinat. Financ. J. 16, 225-260.

Charitou, A., Louca, C., Panayides, S., 2007. Cross-listing bonding hypothesis and corporate governance. J. Bus. Financ. Account. 34 (7\&8), 1281-1306.

Chen, I.J., Lin, S.H., 2014. Managerial optimism, investment efficiency, and firm valuation. Multinat. Financ. J. 17 (3/4), 1-48.

Coles, J.L., Naveen, D.D., Naveen, L., 2008. Boards: does one size fit all? J. Financ. Econ. 87, 329-356.

Cornett, M.M., Marcus, A.J., Tehranian, H., 2008. Corporate governance and pay-for performance: the impact of earnings management. J. Financ. Econ. 87 (2),

Cubbin, J.S., Hall, G., 1983. Directors' remuneration in the theory of the firm: specification and testing of the null hypothesis. Eur. Econ. Rev. 20, 333-348.

Dalton, D.R., Daily, C.M., Ellstrand, A.E., Johnson, J.L., 1998. Meta-analytic reviews of board composition, leadership structure, and financial performance.

Dalton, D.R., Daily, C.M., Johnson, J.L., Ellstrand, A.E., 1999. Number of directors and financial performance: A meta-analysis. Acad. Manag. J. 42 (6), 674-686.

Davidson III, W.N., Xie, B., Xu, W., 2004. Market reaction to voluntary announcements of audit committee appointments: the effect of financial expertise. J.Account. Public Policy 23 (4), 279-293.

Garry, Bruton; Igor ,Filatotchev; Salim, Chahine; Mike, Wright. Governance, Ownership Structure and Performance of IPO Firms:The Impact of Different Types of Private Equity Investors and Institutional Environments. Strategic Management Journal, forthcoming.

Gillan, S., and L. Starks. 2000. Corporate governance proposals and shareholder activism: The role of institutional investors. Journal of Financial Economics 57:275-305.

Aras, G. ,Aybars, A., Kutlu, O. 2008-2009. Investigating the relationship between corporate social responsibility and financial performance in emerging markets. Managing corporate performance.

Nousheen Tariq Bhutta*, Syed Zulfiqar Ali Shah.2014. Investors'Reaction to the Implementation of Corporate Governance Mechanisms. Journal of Accounting, 3, 3-8

Nousheen Tariq Bhutta*, Syed Zulfiqar Ali Shah.2014. Investors'Reaction to the Implementation of Corporate Governance Mechanisms. Journal of Accounting, 3, 3-8

Panayiotis C. Andreou, Christodoulos Louca, Photis M. Panayides, Corporate governance, financial management decisions and firm performance: Evidence from the maritime industry, journal homepage: www.elsevier.com/locate/tre.

Shleifer, A., and R. Vishny. 1997. A survey of corporate governance. Journal of Finance 52:737-83.Strateg. Manag. J. 19 (3), 269-290.

Yermack, D .1996. Higher market valuation of companies with a small board of directors. Journal of Financial Economics, vol. 40, no. 2, pp.185-215. 